\title{
Indigenous Handicrafts in the Pernambuco and Bahia Sertões and Its Implications for the Conservation of Biodiversity
}

\section{Carlos Alberto Batista Santos ${ }^{1}$, Roberto Remígio Florêncio ${ }^{2}$, Vinina da Silva Ferreira ${ }^{3}$, Patrícia Luiza de Oliveira-Rebouças ${ }^{1}$}

\author{
${ }^{1}$ Department of Technology and Social Sciences, State University of Bahia, Juazeiro, Brazil \\ ${ }^{2}$ Department of Biological Sciences, Federal University of the São Francisco Valley, Petrolina, Brazil \\ ${ }^{3}$ Federal Institute of Education, Petrolina, Brazil \\ Email: cacobatista@yahoo.com.br, betoremigio@yahoo.com.br,vininasf@gmail.com,patlu13@gmail.com
}

How to cite this paper: Santos, C. A. B., Florêncio, R. R., da Silva Ferreira, V., \& de Oliveira-Rebouças, P. L. (2018). Indigenous Handicrafts in the Pernambuco and Bahia Sertões and Its Implications for the Conservation of Biodiversity. Creative Education, 9, 2419-2434.

https://doi.org/10.4236/ce.2018.915182

Received: June 27, 2018

Accepted: November 11, 2018

Published: November 14, 2018

Copyright $\odot 2018$ by authors and Scientific Research Publishing Inc. This work is licensed under the Creative Commons Attribution International License (CC BY 4.0).

http://creativecommons.org/licenses/by/4.0/

\begin{abstract}
The use of by-products of wild animals for the production of handicrafts is a common practice among indigenous peoples. Natives prefer to hunt birds because of the beauty and diversity of their feathers. In the Brazilian Northeast, this practice involves several hunting techniques, according to the species type. This research aimed to list the species of birds used in the handicraft of the Truká indigenous people and to characterize the techniques used to capture birds employed by the native hunters in the four ethnic settlements in the backlands of Pernambuco and Bahia. The information was obtained through semi-structured interviews applied to 23 indigenous artisans, in the villages Truká of Cabrobó, Orocó, Sobradinho and Paulo Afonso. Four capture techniques, slingshots, firearms, and traps have been identified, such as the trap and the trapdoor. The traps are the most commonly used technologies in the study area. In addition to crafts, informants have indicated the use of bird species in food, traditional medicine and domestic breeding as pets.
\end{abstract}

\section{Keywords}

Feathering, Hunting and Use of Wildlife, Semiarid, Bird Population

\section{Introduction}

In the Brazilian semi-arid region, areas of the caatinga, wild animals are traditionally used by indigenous societies for various purposes, including the production of handicrafts, mostly ornaments (Almeida et al., 2006; Alves et al., 2010; Alves et al., 2013; Alves, 2012). 
Among the species exploited for artisanal production, birds stand out as one of the most exploited groups (Ferreira \& Glock, 2004; Rocha et al., 2006; Alves et al., 2010). Brazil has one of the richest avifaunae in the world, with an estimated 1825 species (CBRO, 2011), appreciated for its beauty. In our country, hunting is increasing towards this animal group (Rocha et al., 2006; Trinca \& Ferrari, 2006; Barbosa et al., 2010).

To better understand the relationships between man and birds, ethnoornithologists investigate popular knowledge and popular uses about birds, describing and analyzing the information and practices of local populations in the most diverse cultural and ecological contexts (Farias \& Alves, 2007; Sick, 1997). One of the common ways of using these resources is handcraft, here called feather art, a term that refers to artifacts made from bird feathers and used mainly as body adornment by Brazilian native populations (Dorta \& Velthem, 1980; Ribeiro, 1988). Throughout the world, people use bird feathers as body adornments (Biebuyck \& Abbeele 1984). This culture is considered a manifestation of the sensibility that the natives achieved through the observation of nature, the appropriation of the material that impresses it and its elaboration, with the purpose of transferring to him the beauty captured by his eyes (Dorta, 1986). The objects handcrafted by the Indians, mostly have personal use, but we also find the presence of feathers in ritual adornments, which using feathers and down, fixed on supports of vegetable origin or wire, creating headdresses, necklaces, earrings, bracelets, hair clips and various other adornments (Ribeiro, 2009).

Macaw, hawks, owls, herons, parrots are the birds most commonly used in the making of the different Indian adornments in Brazil (Dorta, 1986). It is not possible to use all the plumage of a single bird. Certain parts of the body of the animal cannot be explored. Sometimes only one type of feather is used, which generates a sub-utilization of raw material and the over-exploitation of some species in search of feathers of their preference. The objective of this work was to characterize the handcraft derived from the use of animals available for sale, to list and describe the main techniques used to capture the birds used by the informants, and to evaluate the possible pressures on biodiversity originating from the hunting and use of wild birds in the researched area.

\section{Methodology}

This study was carried out between July 2014 and January 2015 in four Truká villages. Two of them are located in the state of Pernambuco: the mother village, located in the municipality of Cabrobó $\left(8^{\circ} 31^{\prime} 07.11^{\prime \prime} \mathrm{S} \times 39^{\circ} 22^{\prime} 20.87^{\prime \prime} \mathrm{W}\right)$ and another village in the municipality of Orocó $\left(8^{\circ} 36^{\prime} 24.4^{\prime \prime} \mathrm{S} \times 39^{\circ} 34^{\prime} 54.9^{\prime \prime} \mathrm{W}\right)$. The other villages are in the State of Bahia, the one in the municipality of Paulo Afonso $\left(9^{\circ} 25^{\prime} 10.58^{\prime \prime} \mathrm{S} \times 38^{\circ} 16^{\prime} 31.05^{\prime \prime} \mathrm{W}\right)$, the other in the municipality of Sobradinho $\left(9^{\circ} 29^{\prime} 47.7^{\prime \prime} \mathrm{S} \times 40^{\circ} 51^{\prime} 07.9^{\prime \prime} \mathrm{W}\right)$. The island of Asunción, which has an area of about $6000 \mathrm{ha}$, is called the Truká people as the mother village because it originated the Truká settlements in other cities in the sertão of Pernambuco and 
Bahia (Batista, 2005). The villages of Orocó, Paulo Afonso, and Sobradinho (Figure 1), are far from the mother village (Cabrobó), $39.85 \mathrm{~km}, 211.8 \mathrm{~km}$, and $239.18 \mathrm{~km}$ respectively.

The first step to gather data was the identification of Indians who make handicrafts for commercial purposes in the researched areas. After the first contacts, the data about the artisanal capture and production were obtained through the application of semi-structured forms integrated with free individual interviews and complemented with informal conversations (Mello, 1996; Huntington, 2000; Albuquerque \& Lucena, 2004). The forms included data on the age, the level of schooling and occupation of the interviewed, name of the species captured, the reason of choice of that specific species, hunting technique and the use of birds in the production and sale of indigenous handicrafts. Before each interview, interviewed were elucidated on the nature and objectives of our investigation, and we requested the signing of the Informed Consent Form (TCLE) and the authorization term for the use of the image. Authorization for access to traditional knowledge was obtained from the Research Ethics Committee (Opinion No. 723,750), the National Historical and Artistic Heritage Institute (No. 013/2013-01450.010527/2013-30), and the National Foundation of the Indian/Regional Coordination of the Lower São Francisco on $07 / 23 / 2013$.

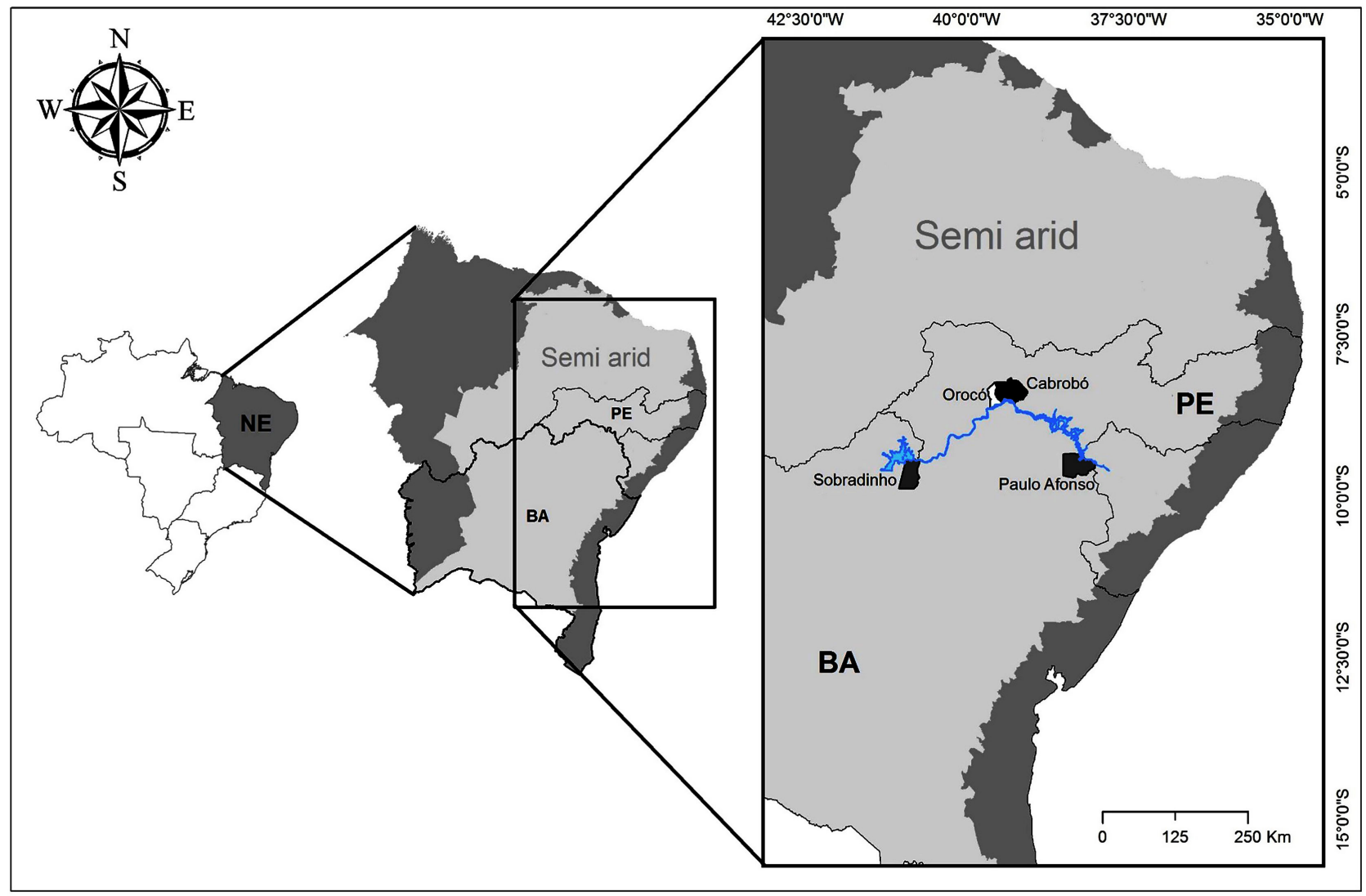

Figure 1. Map of the location of Truká villages in the northeastern semi-arid region. 
The birds were photographed, and their names were recorded based on information provided by their owners. The species were identified according to Alves and Rosa (2006): 1) analysis of photographs of the animals made during the interviews; 2) analysis of the feathers used in the ornaments made by the artisans interviewed; 3) identification according to the vernacular names, with the aid of taxonomists familiar with the fauna of the study areas.

We calculated the relative frequencies of the species mentioned, capture forms and how they were used. The dominant species cited were determined by the formula of Kato et al. (1952). A species was dominant when the value of the lower limit of confidence (LI) was above the limit of dominance (LD). The LD was obtained by the inverse of the total number of captured species multiplied by 100 (Sakagami \& Matsumura, 1967).

Birds diversity was estimated by the Shannon index $\left(\mathrm{H}^{\prime}\right)(1948): \mathrm{H}^{\prime}=-\Sigma \mathrm{pk} \times$ $\ln (\mathrm{pk})$. pk is the proportion of species $\mathrm{k}$ in the sample and the Species of birds in the sample was calculated by the Pielou index $\left(J^{\prime}\right): J^{\prime}=H^{\prime} / H^{\prime} \max$ (Ludwig \& Reynolds, 1988). H'max is the logarithm of the total number of bird species cited.

Similarity analysis among villages was verified by the Jaccard coefficient. This coefficient was used for not considering the shared absences as evidence of similarity, being considered presence/absence data.

The diversity of the birds mentioned was calculated by the Shannon index ( $\left.\mathrm{H}^{\prime}\right)$ (Magurran, 2011), using the algorithm $\mathrm{H}^{\prime}=-\Sigma \mathrm{pk} \times \operatorname{lnpk}$, where pk was the proportion of species $\mathrm{k}$ and $\mathrm{ln}$ is the nepierian logarithm of pk value. The uniformity of the species mentioned was calculated by the Pielou index $\left(J^{\prime}\right)$, using the formula J' = H'/H'max (Ludwig \& Reynolds, 1988), where H'max is the logarithm of the total number of species of Birds cited.

\section{Results and Discussion}

23 indigenous artisans were interviewed. Age ranged from 17 to 68 years. 17 handcrafters were surveyed in Cabrobó, eight in Orocó, seven in Sobradinho and five in Paulo Afonso. They mentioned a total of 38 bird species divided into 36 genera and 21 families (Figure 1).

Among the families of birds registered in this research, the most commonly cited species are Columbidae $(\mathrm{n}=5)$, Ardeidae $(\mathrm{n}=3)$ and Anatidae $(\mathrm{n}=3)$. The Columbidae family also appears in studies (Alves et al., 2009, 2012). The Kato index gave us the dominance limit (LD) observed in this study equal to $2.63 \%$, where 13 species were classified as dominant and together represented $89.7 \%$ of the species most cited by Trukás, from the studied villages (Figure 2).

Among the species of birds reported in the four Truka villages, only one species (Gallus domesticus) was mentioned in the four villages, that is, $100 \%$ constancy was observed about the points sampled. Nine species of birds were shared by three of the four villages investigated. 22 species were only named in only one village (Table 1).

The analysis of similarity, using a qualitative metric (Jaccard index), showed, 
in a general way, a low percentage of similarity between the bird mentioned in the four Trukás villages (Figure 3). The Sobradinho + Orocó group was evidenced, with $47 \%$ similarity. In these villages, eight species were common in the interviews in the two villages in question.

The curve of rarefaction of the birds, mentioned in the Trukás settlements, showed a progressive tendency to stabilize indicating that there was sufficient sampling of the bird species (Figure 4). There was a significant increase in the

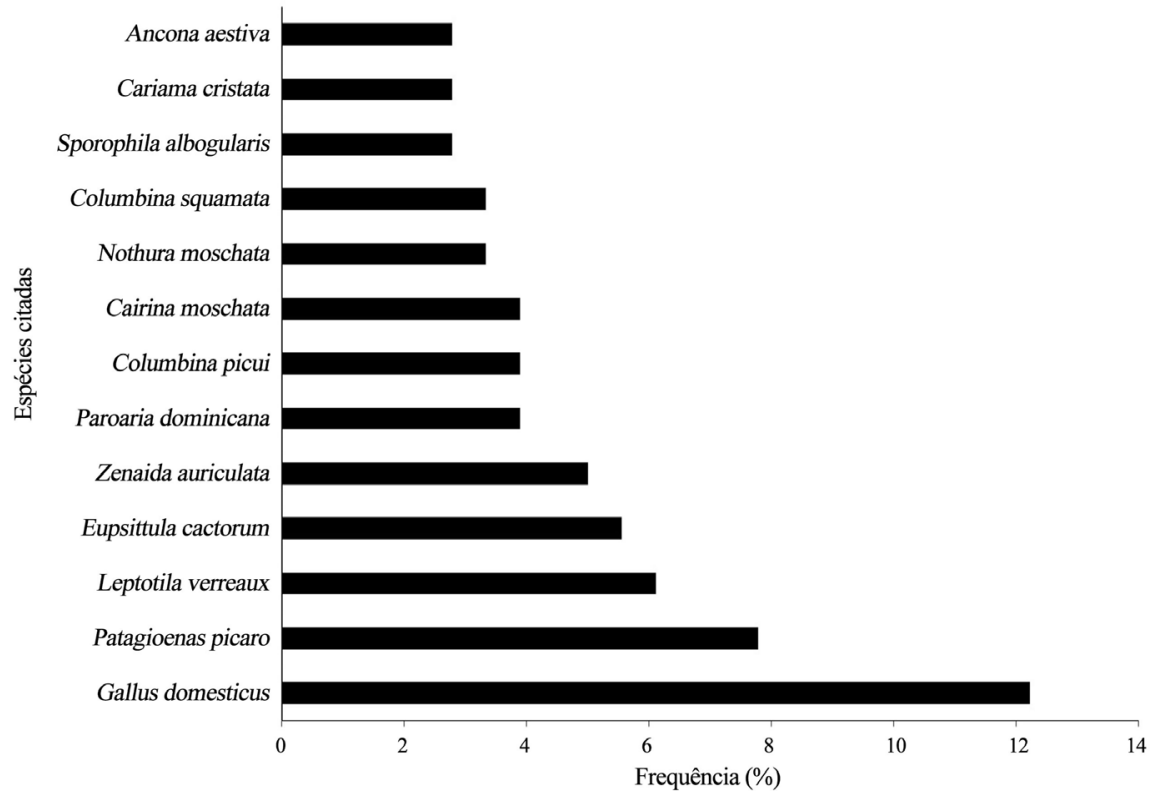

Figure 2. Limit of dominance (LD) of bird species cited by Trukás, calculated from the Kato index $(\mathrm{LD}=2.63 \%)$.

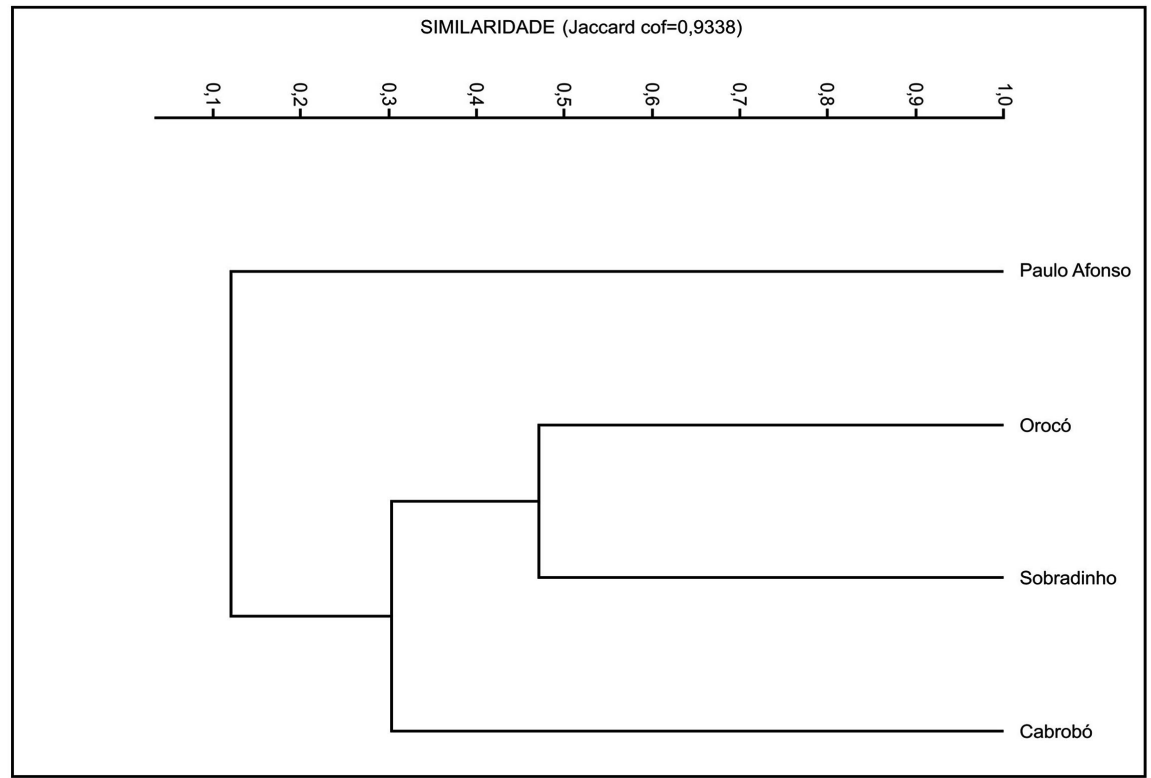

Figure 3. Analysis of grouping using the similarity index of Jaccard, among the birds mentioned in the Truká settlements. The most similar group Sobradinho-Orocó $(\mathrm{J}=47 \%)$, followed by Cabrobó-Orocó $(J=0.3947)$ and Sobradinho-Cabrobó $(J=0.2432)$. 


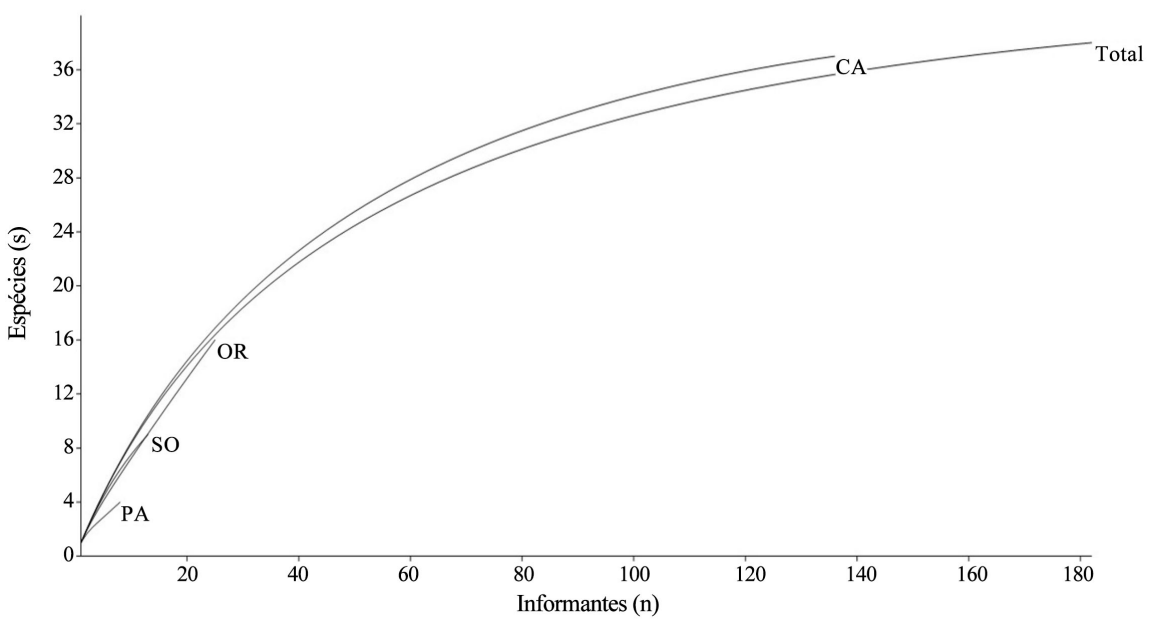

Figure 4. A rarefaction curve with a progressive tendency towards stabilization indicating that there was sufficient sampling of the bird species mentioned in the Truká settlements. PA: Paulo Afonso; SO: Sobradinho; OR: Orocó; CA: Cabrobó.

number of species cited by the informants from the village located in Cabrobó, resulting in stability when we analyze all the data collected in this study. The fact that the largest number of informants interviewed refers to the population located in Cabrobó, may be related to the high number of bird species mentioned during the data collection, compared to the values obtained in the other villages investigated (Table 1).

Due to the stabilization of the accumulation curve of the species, total richness estimators were used from the sample data of the studied community. The results obtained through the non-parametric Chao 1 richness estimator showed, about $94 \%$ of the bird species present in the site related to Truká were cited in this study. In Cabrobó about $94 \%$ of these birds were mentioned. In the other villages, this percentage was less than $70 \%$. This proportion reflected in the rarefaction curves of the villages in Paulo Afonso, Sobradinho and Orocó did not stabilize, suggesting that the increase of samplings could increase the number of estimated species. The value of the diversity index of Shannon $\left(\mathrm{H}^{\prime}\right)$ was equal to 3.37 and oscillated within the Village between 1.07 (Paulo Afonso) and 3.37 (Cabrobó). The Pielou uniformity index was elevated for the study in a general way $\left(\mathrm{J}^{\prime}=0.91\right.$ ), with values ranging from 0.77 (Paulo Afonso) to 0.95 (Sobradinho) (Table 2).

Handcrafters consider three among the 38 species as domestic: gallus (Gallus domesticus), duck (Cairina moschata) and peacock (Pavo cristatus). These species are bred in the backyards among trees, shrubs, and grasses, together with other small domestic animals, growing near the residence (Amaral \& Guarim-Neto, 2008), the remaining species are classified as wild.

In this study, the informants mentioned five purposes of use (feeding, breeding, medicinal, religious and handicraft) and six strategies for the capture of birds (shotgun, hand, bow and arrow, trap and slingshots). The domesticated chicken (Gallus domesticus) was the only species mentioned in the four sampled 
Table 1. Birds used in indigenous Truká handicrafts, conservation status, number of citations per locality.

\begin{tabular}{|c|c|c|c|c|c|c|c|c|c|c|c|c|}
\hline \multirow{2}{*}{ Scientific Name } & \multirow{2}{*}{ Popular Name } & \multirow{2}{*}{$\begin{array}{l}\text { Quotations } \\
\text { (n) }\end{array}$} & \multirow{2}{*}{ IUCN } & \multicolumn{4}{|c|}{ Villages } & \multirow{2}{*}{$\begin{array}{l}\text { No. } \\
\text { Use }\end{array}$} & \multirow{2}{*}{$\begin{array}{c}\text { No. } \\
\text { Capture }\end{array}$} & \multirow{2}{*}{ Villages } & \multirow{2}{*}{ Men } & \multirow{2}{*}{ Women } \\
\hline & & & & CA & OR & $\mathrm{PA}$ & SO & & & & & \\
\hline Gallus domesticus (Linnaeus, 1758) & Chicken & 22 & NL & 7 & 9 & 5 & 1 & 4 & 1 & 4 & $\mathrm{x}$ & $\mathrm{x}$ \\
\hline Cairina moschata (Linnaeus, 1758) & Duck & 16 & NL & 16 & 0 & 0 & 0 & 3 & 4 & 1 & $\mathrm{x}$ & $\mathrm{x}$ \\
\hline $\begin{array}{l}\text { Patagioenas picazuro } \\
\text { (Temminck, 1813) }\end{array}$ & Asa Branca & 14 & $\mathrm{LC}$ & 12 & 1 & 0 & 1 & 2 & 5 & 3 & $\mathrm{x}$ & $\mathrm{x}$ \\
\hline Leptotila verreauxi (Bonaparte, 1855) & Juriti & 11 & $\mathrm{LC}$ & 10 & 1 & 0 & 0 & 3 & 6 & 2 & $\mathrm{x}$ & $\mathrm{x}$ \\
\hline Zenaida auriculata (Des Murs, 1847) & Rebansã & 9 & $\mathrm{LC}$ & 5 & 1 & 0 & 3 & 3 & 4 & 3 & $\mathrm{x}$ & \\
\hline Eupsittula cactorum (Kuhl, 1820) & Piriquitinha & 9 & $\mathrm{LC}$ & 7 & 1 & 0 & 1 & 2 & 1 & 3 & $\mathrm{x}$ & \\
\hline Paroaria dominicana (Linnaeus, 1758 ) & Cardeal & 7 & $\mathrm{LC}$ & 4 & 1 & 0 & 2 & 3 & 4 & 3 & $\mathrm{x}$ & $\mathrm{x}$ \\
\hline Columbina picui (Temminck, 1813) & Rolinha & 7 & $\mathrm{LC}$ & 5 & 1 & 1 & 0 & 2 & 4 & 3 & $\mathrm{x}$ & $\mathrm{x}$ \\
\hline Columbina squammata (Lesson, 1831) & Fogo-Pagou & 6 & $\mathrm{LC}$ & 5 & 0 & 1 & 0 & 3 & 5 & 2 & $\mathrm{x}$ & $\mathrm{x}$ \\
\hline Nothuraboraquira (Spix, 1825) & Codorna & 6 & $\mathrm{LC}$ & 5 & 1 & 0 & 0 & 1 & 3 & 3 & $\mathrm{x}$ & $\mathrm{x}$ \\
\hline Sporophila albogularis (Spix, 1825) & Golinho & 5 & $\mathrm{LC}$ & 2 & 1 & 0 & 2 & 3 & 4 & 3 & $\mathrm{x}$ & \\
\hline Cariama cristata (Linnaeus, 1766) & Sariema & 5 & $\mathrm{LC}$ & 4 & 0 & 0 & 1 & 2 & 3 & 2 & $\mathrm{x}$ & $\mathrm{x}$ \\
\hline Amazona aestiva (Linnaeus, 1758) & Parrot & 5 & $\mathrm{LC}$ & 4 & 1 & 0 & 0 & 1 & 1 & 2 & $\mathrm{x}$ & $\mathrm{x}$ \\
\hline Pavo cristatus (Linnaeus, 1758) & Peacock & 4 & $\mathrm{LC}$ & 2 & 1 & 0 & 1 & 3 & 3 & 2 & $\mathrm{x}$ & \\
\hline Crotophaga ani (Linnaeus, 1758) & Anu Preto & 4 & $\mathrm{LC}$ & 2 & 1 & 1 & 0 & 3 & 3 & 1 & $\mathrm{x}$ & \\
\hline $\begin{array}{c}\text { Amazonetta brasiliensis } \\
\text { (Gmelin, 1789) }\end{array}$ & Marreca & 4 & $\mathrm{LC}$ & 4 & 0 & 0 & 0 & 2 & 4 & 1 & $\mathrm{x}$ & $\mathrm{x}$ \\
\hline $\begin{array}{l}\text { Rhynchotus rufescens } \\
\text { (Temminck, 1815) }\end{array}$ & Perdiz & 4 & $\mathrm{LC}$ & 4 & 0 & 0 & 0 & 2 & 3 & 1 & $\mathrm{x}$ & $\mathrm{x}$ \\
\hline Dendrocygna viduata (Linnaeus, 1766) & Paturi & 4 & $\mathrm{LC}$ & 4 & 0 & 0 & 0 & 2 & 3 & 1 & $\mathrm{x}$ & \\
\hline $\begin{array}{l}\text { Sporophila bouvreuil } \\
\text { (Statius Muller, 1776) }\end{array}$ & Caboclinho & 4 & $\mathrm{LC}$ & 4 & 0 & 0 & 0 & 1 & 2 & 3 & $\mathrm{x}$ & \\
\hline Sicalis flaveola (Linnaeus, 1766) & Canário & 4 & NL & 2 & 2 & 0 & 0 & 1 & 2 & 3 & $\mathrm{x}$ & \\
\hline Cyanocorax cyanopogon (Wied 1821) & Cancão & 4 & $\mathrm{LC}$ & 4 & 0 & 0 & 0 & 1 & 1 & 1 & $\mathrm{x}$ & \\
\hline Aramusguarauna (Linnaeus, 1766) & Carão & 3 & $\mathrm{LC}$ & 1 & 1 & 0 & 1 & 2 & 3 & 1 & $\mathrm{x}$ & $\mathrm{x}$ \\
\hline Podilymbus podiceps (Linnaeus, 1758) & Mergulhão & 3 & $\mathrm{LC}$ & 3 & 0 & 0 & 0 & 2 & 3 & 1 & $\mathrm{x}$ & $\mathrm{x}$ \\
\hline $\begin{array}{l}\text { Cyanoloxiabrissonii } \\
\text { (Lichtenstein, 1823) }\end{array}$ & Azulão & 3 & $\mathrm{LC}$ & 3 & 0 & 0 & 0 & 1 & 2 & 3 & $\mathrm{x}$ & \\
\hline Pseudoseisura cristata (Spix, 1824) & Casaca-De-Couro & 2 & $\mathrm{LC}$ & 2 & 0 & 0 & 0 & 3 & 3 & 1 & $\mathrm{x}$ & \\
\hline Caracara plancus (Miller, 1777) & Carcará & 2 & $\mathrm{LC}$ & 2 & 0 & 0 & 0 & 2 & 3 & 2 & $\mathrm{x}$ & \\
\hline Rupornismagnirostris (Gmelin, 1788) & Eagle Carijó & 2 & $\mathrm{LC}$ & 2 & 0 & 0 & 0 & 2 & 3 & 1 & $\mathrm{x}$ & \\
\hline Bubulcus íbis (Linnaeus, 1758) & Heron Carrapateira & 2 & $\mathrm{LC}$ & 2 & 0 & 0 & 0 & 2 & 3 & 1 & $\mathrm{x}$ & \\
\hline Egretta thula (Molina, 1782) & Heron Pequena & 2 & $\mathrm{LC}$ & 2 & 0 & 0 & 0 & 2 & 3 & 1 & $\mathrm{x}$ & \\
\hline Ardea alba (Linnaeus, 1758) & Big Heron & 2 & $\mathrm{LC}$ & 1 & 1 & 0 & 0 & 2 & 3 & 1 & $\mathrm{x}$ & \\
\hline $\begin{array}{l}\text { Anodorhynchus leari } \\
\text { (Bonaparte, 1856) }\end{array}$ & $\begin{array}{l}\text { Arara-Azul- } \\
\text { De-Lear }\end{array}$ & 2 & $\mathrm{E}$ & 2 & 0 & 0 & 0 & 2 & 3 & 1 & $x$ & \\
\hline
\end{tabular}


Continued

\begin{tabular}{|c|c|c|c|c|c|c|c|c|c|c|c|}
\hline $\begin{array}{l}\text { Turdusamaurochalinus } \\
\text { (Cabanis, 1850) }\end{array}$ & Sabiá Poca & 2 & LC & 2 & 0 & 0 & 0 & 2 & 2 & 1 & $\mathrm{x}$ \\
\hline Pitangus sulphuratus (Linnaeus, 1766) & Bem-Te-Vi & 2 & LC & 2 & 0 & 0 & 0 & 2 & 2 & 1 & $\mathrm{x}$ \\
\hline Icterus jamacaii (Gmelin, 1788) & Sofrê & 1 & LC & 1 & 0 & 0 & 0 & 2 & 2 & 1 & $\mathrm{x}$ \\
\hline $\begin{array}{c}\text { Colaptesmelanochloros } \\
\text { (Gmelin, 1788) }\end{array}$ & Pica-Pau & 1 & $\mathrm{LC}$ & 1 & 0 & 0 & 0 & 2 & 2 & 1 & $\mathrm{x}$ \\
\hline Antrostomus rufus (Boddaert, 1783) & Bacurau & 1 & LC & 1 & 0 & 0 & 0 & 2 & 2 & 1 & $\mathrm{x}$ \\
\hline Nyctibius griséus (Gmelin, 1789) & $\begin{array}{c}\text { Coruja } \\
\text { Mãe-Da-Lua }\end{array}$ & 1 & LC & 1 & 0 & 0 & 0 & 2 & 2 & 1 & $\mathrm{x}$ \\
\hline Athene cunicularia (Molina, 1782) & Coruja Buraqueira & 1 & LC & 1 & 0 & 0 & 0 & 2 & 2 & 1 & $\mathrm{x}$ \\
\hline Megascops choliba (Vieillot, 1817) & Corujinha & 1 & LC & 1 & 0 & 0 & 0 & 2 & 2 & 1 & $\mathrm{x}$ \\
\hline Coragyps atratus (Bechstein, 1793) & Vulture & 1 & LC & 0 & 1 & 0 & 0 & 2 & 1 & 1 & $\mathrm{x}$ \\
\hline
\end{tabular}

Subtitle: LR-Lower risk, LC—Least concern, E-Endangered, V—Vulnerable (Categories of IUCN), NL-Not listed on IUCN.

Table 2. Data on richness, abundance, diversity (Shannon-H' Index) and uniformity (Pielou-J Index), by Truká villages surveyed.

\begin{tabular}{|c|c|c|c|c|c|}
\hline & \multicolumn{4}{|c|}{ Researched Villages } & \multirow[b]{2}{*}{ Total } \\
\hline & Cabrobó & Orocó & Paulo Afonso & Sobradinho & \\
\hline Number of informants & 17 & 8 & 5 & 7 & 37 \\
\hline Capture Forms & 6 & 5 & 3 & 5 & 6 \\
\hline Forms of use & 4 & 5 & 2 & 3 & 5 \\
\hline Bird species (s) & 37 & 16 & 4 & 9 & 38 \\
\hline Abundance (n) & 128 & 25 & 8 & 13 & 174 \\
\hline Diversity (H') & 3.373 & 2.372 & 1.074 & 2.098 & 3.378 \\
\hline Uniformity (J') & 0.934 & 0.856 & 0.774 & 0.955 & 0.912 \\
\hline Chao 1 & 41.15 & 61.5 & 7 & 14 & 42.1 \\
\hline
\end{tabular}

villages, with the highest number of citations ( $\mathrm{n}=22$ citations), showing a higher frequency $(\mathrm{Fr}=12.2$ ), being captured only by one type of strategy (by hand). This bird is used by the Truká Indians in the making of body adornments since it is the most available species. Their feathers are dyed with various color paints, a custom called "tapir" (Teixeira, 1992; Cascudo, 2012). Most colored plumage birds are wild and therefore protected by conservation treaties. For this reason, Truká Indians reduced the capture of these species, although it does not prevent their use. Beside handicrafts, chicken feathers are also used for other purposes: medicinal, food and religious. The second most used species, Cairinamoschata (duck) ( $\mathrm{n}=16$ citations), is also bred in backyards. Record of the use of duck feathers for the production of body adornments between the Karajá and Tapirapé Natives, were made by Nicola and Dorta (1982). The third species that is 
bred in the backyards is the Pavocristatus (peacock) ( $\mathrm{n}=4$ citations). Its use has been recorded in the Indian handicraft of the Kayabi and Bororós people (Nicola \& Dorta, 1982; Dorta, 1986).

In addition to the crafts, the birds cited by the interviewees have several utilities for the Truká people: feeding, traditional medicine, ritual use and as pets. We often found the same species with various purposes, such as the domestic chicken, hen and duck, and the wild species Zenaida auriculata (rebansã), Columbina picui (Roller) and Patagioenas picazuro (white wing), raised as pets, used in handicrafts and food.

In this study, $60 \%$ of the species mentioned were used for two diffferent purposes, $22.5 \%$ for three different purposes, $15 \%$ with one type of use and only one species $(2.5 \%)$ was explored in four different ways. The diversification of uses of the same species optimizes the use of these resources (Moura \& Marques, 2008), the chicken was the only species of the bird that had records of use in religious rituals among the people Truká: the Xangô ritual. Among the forms of use mentioned among the interviewees, the food was the most frequently used (53\%), followed by handicrafts $(18 \%)$, breeding $(18 \%)$, medicinal $(10 \%)$ and religious (1\%).

The wild species cited in this study have been classified as of low concern by the International Union for Conservation of Nature-IUCN (2012), except Anodorhynchusleari, classified as endangered (Figure 1). In the Truká villages we studied, we recorded three records for this species: one of the informant's reported the use of macaw feathers but did not hunt the species. The feathers he was using had been exchanged with other indigenous peoples for Birds found in the village itself. Previous studies recorded the use of macaw feathers in indigenous handicrafts for the Tapirapé, Tukano, Kaiapó, Kaxináwa, Urubu-kaapor and Kayabi peoples (Nicola \& Dorta, 1982) and Bororós (Dorta, 1986).

Truká natives also use the feathers of other species of birds for their handicrafts: the hawks by the Bororós, Tukano and Kayabi; the parrots by the Bororós, Tapirapé, Tukano and Kayabi; the heron through the Palikur, Tapirapé, Kayabi and Karajá; the owls by the Kayabi natives (Nicola \& Dorta, 1982; Dorta, 1986) and Urubus by the Bororós (Dorta, 1986).

Craft production by the Truká people is more intense in the village of Cabrobó. Local informants quoted the artisanal use of 33 of the 38 species used by the Truká people, the vulture being the exception. Orocó village appears in second place with 16 species used, four of which are locally used in the production of handicrafts. The largest number of species used in the villages of Cabrobó and Orocó can be explained by the proximity of the villages, about $39.85 \mathrm{~km}$, and their location in islands of the Submédio São Francisco River region. These areas are characterized by hyperxerophilic caatinga vegetation with stretches of abundant deciduous forest (SGB, 2005a; 2005b), where the practice of hunting is maintained as a cultural trait.

In the village of Truká de Sobradinho, the hen was the only species cited for 
artisanal purposes, this particular characteristic is explained by the prohibition of hunting birds by Cacique Truká of the village of Paulo Afonso. According to him, "the charms of light gave this orientation and here nobody can hunt any flying bug".

In the village of Sobradinho, we only registered an artisan who uses only the chicken to make ornaments because it is not favorable to hunting. In these villages, ornate headdresses and maracásare acquired from the Truká artisans of Cabrobó. In the artifacts, feathers are used with other materials, such as shells, cotton threads, seeds, hairs, teeth and bones of mammals, or vegetal fiber, being generally used the caroá Neoglaziovia variegata (Arruda) Mez. Feathers are cut in different shapes or dyed with inks of different colors. The basic procedure for joining the feathers is the lashing and gluing of these feathers in the 'feather line' as described by Nicola \& Dorta (1982).

Handicrafts and feeding were the forms of use of the birds mentioned in this study that obtained the highest richness of registered bird species, 39 and 32 species respectively. The values of the diversity index $\left(\mathrm{H}^{\prime}\right)$ for the species of birds cited for handicrafts and feeding were the highest among the mentioned purposes of use, being respectively 3.41 and 2.93. Regarding the use of bird species for handicrafts and food, high uniformity was observed $\left(\mathrm{J}^{\prime}=0.98\right.$ and $\mathrm{J}^{\prime}=0.85$ respectively), that is, there is no preference or concentration of use of single bird species in these two Types of usage mode (Table 2).

The choice of species is mainly due to the color of the feathers and the beauty of the song (Barbosa et al., 2010; Santos, Dâmaso, \& Almeida-Júnior, 2012), according to the informants, birds captured are not commercialized in the region. These serve the domestic breeding, feeding, and production of handicrafts, mainly feathers, but also beaks and nails.

Breeding birds for handicrafts production use is a strategy used by the Truká Indians in the Brazilian Northeast. We observed eight indigenous artisans, all of them living in the village of Cabrobó, who breed colored birds like parrots (Amazona aestiva), parakeets (Eupsittula cactorum), sofrê (Icterus jamacaii) and cancao (Cyanocorax cyanopogon) (Figure 5), to provide feathers for making various types of adornments. Pezzuti \& Chaves (2009) observed breeding colored birds to subsidize handicrafts is a part of the native culture, transmitted orally from one generation to the next.

In addition to the use of parts of the birds in the handicraft, we recorded the use of birds in traditional medicine Truká. In this study we observed the medicinal use of the duck (Cairina moschata), whose egg is used to treat weakness, and the chicken (Gallus domesticus), which uses lard, oil and feces, for the treatment of burns, inflammation, "frighten bad entities", weakness, pain, flu, sore throat, earache, stuffy nose, wounds, sore throat, headache, hair growth, hair loss, and nasal clearing. The use of these species in traditional medicine had already been recorded in previous studies (Alves et al., 2012; Ferreira et al., 2012; Bezerra, Araújo, Alves, \& Alves, 2013). 


\section{The Capture of Wild Birds}

The decree number 6040 , Art. $3^{\circ}$, aims to guarantee to the traditional peoples and communities their territories and access to the natural resources that they traditionally use for their physical, cultural and economic reproduction. Indigenous peoples have this right ratified by Law no. 6001/1973 art. 24, (Brazil, 1973), which allows them to practice hunting and fishing in the areas they occupy. Hunting and birding by indigenous populations has been described in recent studies (Costa-Neto, 1999; Lima \& Santos, 2010; Pereira \& Schiavetti, 2010). In the Trukás Villages investigated in this study the most frequent form of capture of the birds was the capture using the hands ( $24 \%$ of the captured forms), followed by shotgun (21\%), slingshot (18\%), archery (14\%), trapdoor (12\%) and trap (11\%) (Figure 2). The richness of bird species cited for these capture methods ranged from five to 31 species, the diversity index values $\left(\mathrm{H}^{\prime}\right)$ was between 1.37 and 3.37, and the uniformity values $\left(J^{\prime}\right)$ varied between 0.85 to 1 (Table 3 ).

Aware of bird habits, the Trukas Natives go a hunting early in the morning, or late afternoon, when the temperature is milder and birds go searching for food. The techniques used in the capture are passed down from one generation to the following. Children follow the fathers during the hunts, where they use slingshots, firearms (Figure 6) or different types of traps (armadilhas, arapucas, alçapão), when captive breeding is intended. Similar records of capture techniques were performed by Alves et al., 2009; Alves et al., 2013; Bezerra, Araújo, \& Alves, 2012; Nóbrega \& Daflon, 2009; Barbosa et al., 2010.

Firearms represent a basic tool for many hunters in the Brazilian semi-arid because it is a more efficient method than traditional ones (Alves et al., 2009). Several Trukás artisans $(n=20)$ consider this approach as inadequate for the hunting of birds because it causes the destruction of most of the feathers. The use of the shotgun was the second most cited capture method in this study ( $\mathrm{n}=$ 44), however, only 18 bird species were associated with this method (Table 3), resulting in a moderate diversity of species related to capture by firearm.

Truká natives frequently use traps and box traps for the capture of birds by Truká natives. According to our study, 12 and 13 species of birds, respectively, are often captured by these two artifacts.

The "box trap" (arapuca) is built with small pieces of wood, armed in the middle of the vegetation. Below the trap is placed a "bait", such as fruits and seeds, to attract the birds. This technique has been described to capture larger species like Rebansã (Zenaida auriculata). The trapdoor (alçapão) is a type of cage designed to catch songbirds that will be bred in captivity. Domestication of animals is one of the hallmarks of the development of civilization (Beck \& Katcher, 1996). Among various utilities, animal products provide nutrition, transportation, companionship, entertainment and income (Scanes, 2003). An example of the use of this animal by Truká Natives is the production of body adornments that they will sell later in the urban centers surrounding their villages. 

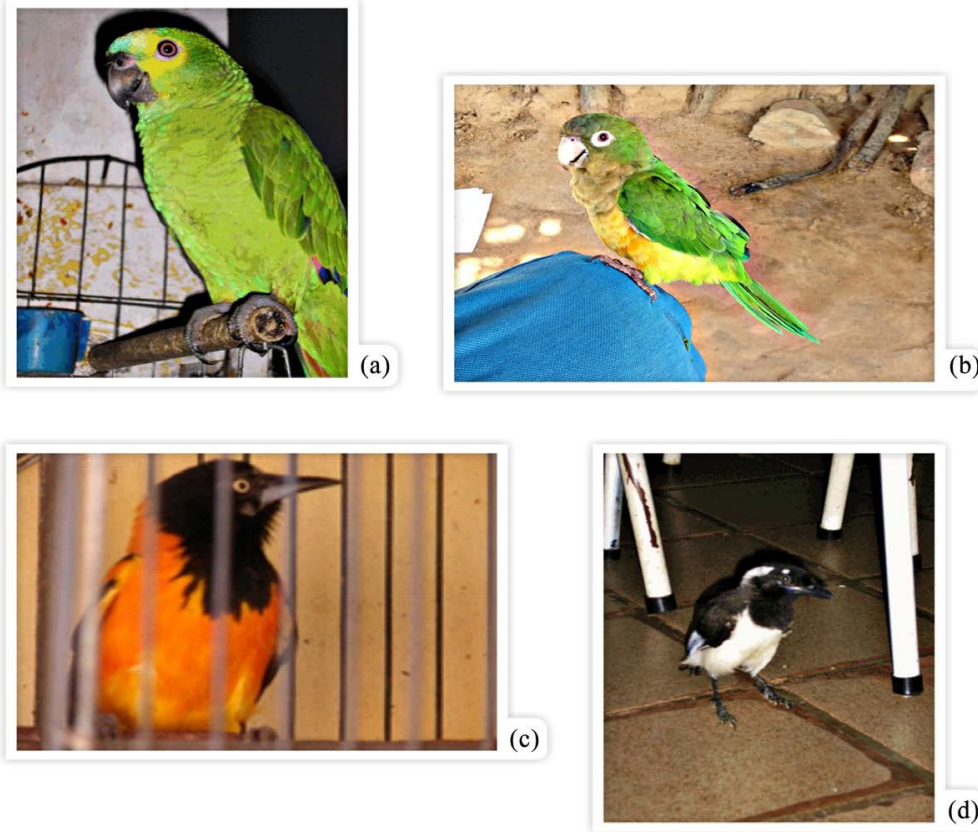

Figure 5. $\mathrm{A}=$ Perrot (Amazona aestiva); $\mathrm{B}=$ Periquitinha (Eupsittulacactorum); $\mathrm{C}=$ Sofrê (Icterus jamacaii) $; \mathrm{D}=$ Cancão (Cyanocorax cyanopogon).
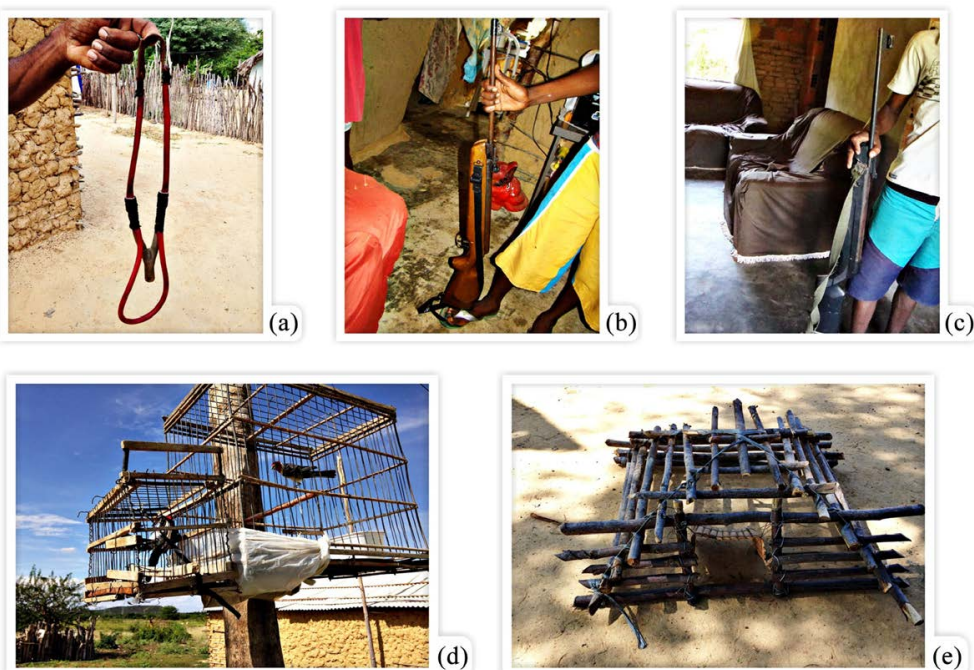

Figure 6. $\mathrm{A}=$ Slingshot; $\mathrm{B}=$ Shotgun pelleet; $\mathrm{C}=$ Cartridge rifle; $\mathrm{D}=$ Hatch; $\mathrm{E}=$ Trap.

Table 3. Capture forms and uses of Avifauna cited in Truká settlements, diversity analyses (Shannon- $\mathrm{H}$ 'index) and uniformity (Pielou-J' Index).

\begin{tabular}{cccccccccccc}
\hline & \multicolumn{1}{c}{ Capture } & \multicolumn{1}{c}{ Use } \\
\hline & Shotgun & Hand & Archery & Trap & Trapdoor & Trap & Food & Breeding & Medicinal & Religious & Crafts \\
\hline $\mathrm{N}^{\circ}$ of citations & 44 & 50 & 29 & 23 & 26 & 37 & 127 & 44 & 23 & 2 & 43 \\
$\mathrm{~N}^{\circ}$ of species & 18 & 5 & 29 & 12 & 13 & 31 & 32 & 13 & 3 & 2 & 33 \\
Diversity (H') & 2.711 & 1.371 & 3.367 & 2.281 & 2.471 & 3.372 & 2.93 & 2.356 & 0.919 & 0.6931 & 3.414 \\
Uniformity $\left(J^{\prime}\right)$ & 0.9379 & 0.8521 & 1 & 0.9178 & 0.9635 & 0.9819 & 0.8453 & 0.9185 & 0.8365 & 1 & 0.9765 \\
\hline
\end{tabular}




\section{Final Considerations}

The capture and use of wild birds are widespread practices in Truká villages. This activity has a close relationship with local culture and economy. Article 23 of the Convention on Biological Diversity stresses that hunting, fishing and gathering activities carried out by natives populations shall be recognized as important factors in maintaining the culture of these peoples (Pozo-Ripário \& Eras, 2009; Santos \& Costa Neto, 2007).

However, the use of natural resources must reconcile human needs with the protection of natural resources (Andriguetto-Filho et al., 1998). The continuity and intensification of the capture of wild birds may cause damages to local biodiversity. Conservation measures should be carried out to minimize pressures on local birds, taking into account the cultural aspects associated with the use of these animals. Educational strategies should be pursued in conjunction with the indigenous population, considering the problems that may arise from the local extinction of birds species. An example of such problems may be the disappearance of Truká feather art, associated either with the reduction of bird biodiversity or economic difficulties, which may suggest the substitution of natural feathers for other materials, such as wires and beads.

The use of alternative materials by artisans has already been done to increase the trade of indigenous handicrafts, changing the way of making handicrafts, transforming and de-characterizing traditional feathers.

\section{Conflicts of Interest}

The authors declare no conflicts of interest regarding the publication of this paper.

\section{References}

Albuquerque, U. P., \& Lucena, R. F. P. (2004). Métodos e técnicas na pesquisa etnobotânica. Recife: NUPEEA.

Almeida, S. M., Franchin, A. G., \& Marçal-Júnior, O. (2006). Estudoetnoornitológico no distrito rural de Florestina, município de Araguari, região do TriânguloMineiro, Minas Gerais. Sitientibus Série Ciências Biológicas, 6, 26-36.

Alves, R. R. N. (2012). Relationships between Fauna and People and the Role of Ethnozoology in Animal Conservation. Etnobiology and Conservation, 1, 1-69. https://doi.org/10.15451/ec2012-8-1.2-1-69

Alves, R. R. N., Gonçalves, M. B. R., \& Vieira, W. L. S. (2012). Caça, uso e conservação de vertebrados no semiáridoBrasileiro. Tropical Conservation Science, 5, 94-416. https://doi.org/10.1177/194008291200500312

Alves, R. R. N., Leite, R. C. L., Souto, W. M. S., Bezerra, D. M. M., \& Loures-Ribeiro, A. (2013). Ethno-Ornithology and Conservation of Wild Birds in the Semi-Arid Caatinga of Northeastern Brazil. Journal of Ethnobiology and Ethnomedicine, 9, 1-12. https://doi.org/10.1186/1746-4269-9-14

Alves, R. R. N., Mendonça, L. E. T., Confessor, M. V. A., Vieira, W. L. S., \& Lopez, L. C. S. (2009). Hunting Strategies Used in the Semi-Arid Region of Northeastern Brazil. Journal of Ethnobiology and Ethnomedicine, 5, 1-16. 
https://doi.org/10.1186/1746-4269-5-12

Alves, R. R. N., Oliveira, M. G. G., Barboza, R. R. D., \& Lopez, L. C. S. (2010). An Ethnozoological Survey of Medicinal Animals Commercialized in the Markets of Campina Grande, NE Brazil. Human Ecology Review, 7, 11-17.

Amaral, C. N., \& Guarim-Neto, G. (2008). Osquintaiscomoespaços de conservação e cultivo de alimentos: um estudonacidade de Rosário Oeste (Mato Grosso, Brasil). Boletim Museu Paranaense Emílio Goeldi. Ciências Humanas, 3, 329-341.

Andriguetto-Filho, J. M., Krüger, A. C., \& Lange, M. B. R. (1998). Caça, biodiversidade e gestãoambientalna Área de Proteção Ambiental de Guaraqueçaba, Paraná, Brasil. Biotemas, 11, 133-156.

Barbosa, J. A. A., Nóbrega, V. A., \& Alves, R. R. N. (2010). Aspectos da caça e comércioilegal da avifauna silvestreporpopulaçõestradicionais do semiáridoparaibano. Revista de Biologia e Ciências da Terra, 10, 39-49.

Batista, M. R. R. (2005). Descobrindo e recebendoheranças: As lideranças Truká. Tese (Doutoradoem Antropologia). Universidade Federal do Rio de Janeiro, Departamento de Antropologia Social, 279 p.

Beck, A. M., \& Katcher, A. H. (1996). Between Pets and People: The Importance of Animal Companionship. West Lafayette, IN: Purdue University Press.

Bezerra, D. M. M., Araújo, H. F. P., \& Alves, R. R. N. (2012). Captura de aves silvestres no semiárido brasileiro: técnicas cinegéticas e implicações para conservação. Tropical Conservation Science, 5, 50-66. https://doi.org/10.1177/194008291200500106

Bezerra, D. M. M., Araujo, H. F., Alves, A. G., \& Alves, R. R. N. (2013). Birds and People in Semiarid Northeastern Brazil: Symbolic and Medicinal Relationships. Journal of Ethnobiology and Ethnomedicine, 9, 1-20. https://doi.org/10.1186/1746-4269-9-3

Biebuyck, D. P., \& Abbeele, N. V. D. (1984). The Power of Headdresses, a Cross-Cultural Study of Forms and Functions. Brussels: Published under the Patronage of Leopold III Foundation for Exploration and Nature Conservation.

Brasil (1973). Lei n 6.001 de 19 de dezembro de 1973. Brasilia: Dispõesobre o Estatuto do Índio. http://www.planalto.gov.br/ccivil_03/LEIS/L6001.htm

Cascudo, L. C. (2012). Dicionário do Folclorebrasileiro. Rio de Janeiro: Global.

Comitê Brasileiro de Registros Ornitológicos, CBRO. (2011). Lista de Aves do Brasil (10th Ed.). http://urlm.com.br/www.cbro.org.br

Costa-Neto, E. M. (1999). Recursos Animais Utilizados Na Medicina Tradicional dos índios Pankararéquehabitam no Nordeste do estado da Bahia, Brasil. Actualidades Biologicas, 1, 69-79.

Dorta, S. F. (1986). Plumária Borôro. In D. Ribeiro (Ed.), Suma Etnológica Brasileira, Volume 3, Arte índia (pp. 227-236). Rio de Janeiro: Vozes.

Dorta, S. F., \& Velthem, L. H. (1980). Arte plumária no Brasil. Catálogo de exposição. Brasília: Fundaçãonacional Pró-Memória.

Farias, G. B., \& Alves, A. G. C. (2007). É importantepesquisar o nome local das aves? Revista Brasileira de Ornitologia, 15, 403-408.

Ferreira, C. M., \& Glock, L. (2004). Diagnósticopreliminarsobrea avifauna traficada no Rio Grande do Sul, Brasil. Biociências, 12, 21-30.

Ferreira, F. S., Albuquerque, U. P., Coutinho, H. D. M., Almeida, W. O., \& Alves, R. R. N. (2012). The Trade in Medicinal Animals in Northeastern Brazil. Evidence-Based Complementary and Alternative Medicine, 2012, Article ID: 126938.

https://doi.org/10.1155/2012/126938 
Huntington, H. P. (2000). Using Traditional Ecological Knowledge in Science: Methods and Applications. Ecological Applications, 10, 1270-1274.

International Union for Conservation of Nature, IUCN (2012). Red List of Threatened Species. http://www.iucnredlist.org/

Kato, M. M. T., \& Yamashita, Z. (1952). Associative Ecology of Insects Found in the Paddy Field Cultivated by Various Planting Forms. Sciences Reports of the Tohoku University, 19, 291-301.

Lima, J. R. B., \& Santos, C. A. B. (2010). Recursos Animais Utilizados Na Medicina Tradicional dos índios Pankararú no nordeste do Estado de Pernambuco, Brasil. Etnobiología, 8, 39-50.

Ludwig, J., \& Reynolds, J. (1988). Statistical Ecology: A Primer on Methods and Computing. New York, NY: John Wiley Sons.

Magurran, A. (2011). Medindo a diversidadebiológica. Curitiba: Editora UFPR.

Mello, L. C. (1996). Antropologia Cultural. Iniciação, teoria e temas. Rio de janeiro, Brasil: Vozes, Petrópolis.

Moura, F. B. P., \& Marques, J. G. W. (2008). Zooterapia popular na Chapada Diamantina: Uma Medicina incidental? Ciência \& Saúde Coletiva, 13, 2179-2188. https://doi.org/10.1590/S1413-81232008000900023

Nicola, N., \& Dorta, S. F. (1982). Arte plumária do Brasil. São Paulo: Mercedes-Benz do Brasil S.A.

Nóbrega, R. A., \& Daflon, V. T. (2009). Da escravidão às migrações: Raça e etnicidade nas relações de trabalho no Brasil. In XXVIII International Congress of the Latin American Studies Association. Rio de Janeiro: Website da Latin American Studies Association.

Pereira, J. P. R., \& Schiavetti, A. (2010). Conhecimentos e usos da fauna cinegética pelos caçadores indígenas “Tupinambá de Olivença” (Bahia). Biota Neotropica, 10, 175-183. https://doi.org/10.1590/S1676-06032010000100018

Pezzuti, J., \& Chaves, R. P. (2009). Etnografia e manejo de recursos naturais pelo índios Deni, Amazonas, Brasil. Acta Amazônica, 39, 121-138.

https://doi.org/10.1590/S0044-59672009000100013

Pozo-Ripário, W. E., \& Eras, M. A. (2009). Diversidad y usos de aves de bosques ribereños remanentes en fincas de Santo Domingo de los Tsáchilas. Ciencia, 12, 180-203.

Ribeiro, B. (1988). Dicionário de artesanatoindígena. São Paulo: Editora da Universidade de São Paulo.

Ribeiro, B. (2009). Bases para umaclassificação dos adornosplumários dos índios do Brasil. In D. Ribeiro (Ed.), Suma Etnológica Brasileira (Vol. 3, pp. 189-226). Rio de Janeiro: Vozes.

Rocha, M. S. P., Cavalcanti, P. C. M., Sousa, R. L., \& Alves, R. R. N. (2006). Aspectos da comercializaçãoilegal de avesnasfeiraslivres de Campina Grande, Paraíba, Brasil. Revista de Biologia e Ciências da Terra, 6, 204-221.

Sakagami, S. F., \& Matasumura, T. (1967). Relative Abundance, Phenology and Flower Preference of Andrenid Bees in Sapporo, North Japan (Hymenoptera, Apoidea). Japanese Journal of Ecology, 17, 237-250.

Santos, C. A. B., Dâmaso, R. C. S. C., \& Almeida-Júnior, V. D. (2012). Caracterização da avifauna da área de proteçãoambiental do lago de Sobradinho: Levantamentorápido e osproblemas de conservação. In C. A. B. Santos, \& E. M. S. Nogueira (Eds.), Biodiversidade da caatinga do Submédio e baixo São Francisco (pp. 37-47). Salvador: Eduneb.

Santos, I. B., \& Costa-Neto, E. M. (2007). Estudo Etna Ornitológico Em Uma Região do 
semiárido do estado da Bahia, Brasil. Sitientibus Série Ciências Biológicas, 7, 273-288.

Scanes, C. G. (2003). Biology of Growth of Domestic Animals. Cambridge: Wiley-Blackwell.

SGB, Serviço Geológico do Brasil. (2005a). Projeto cadastro de fontes de abastecimentopor água subterrânea. Diagnóstico do município de Orocó, estado de Pernambuco. Recife: CPRM/PRODEEM. http://www.cprm.gov.br

SGB, Serviço Geológico do Brasil. (2005b). Projeto cadastro de fontes de abastecimento por água subterrânea. Diagnóstico do município de Cabrobó, estado de Pernambuco. Recife: CPRM/PRODEEM. http://www.cprm.gov.br

Sick, H. (1997). Ornitologia Brasileira. Rio de Janeiro: Nova Fronteira.

Teixeira, D. (1992). Perspectivas da etno-ornitologia no Brasil: O exemplo de um estudosobre a "tapiragem". Boletim do Museu Paraense Emilio Göeldi, 8, 113-121.

Trinca, C. T., \& Ferrari, S. (2006). Caçaemassentamento rural na amazonia matogrossense. In P. Jacobi, \& L. C. Ferreira (Eds.). Diálogos em Ambiente e sociedade no Brasil (pp. 155-167). Indaiatuba: ANPPAS, Annablume. 